\title{
Observation of a Gelatinous Octopod, Haliphron atlanticus, along the Southern West Mariana Ridge: A Unique Cephalopod of Continental Slope and Mesopelagic Communities
}

\author{
Michael J. Miller ${ }^{1},{ }^{1}$ Tetsuya Miwa, ${ }^{2}$ Shun Watanabe, ${ }^{3}$ Mari Kuroki, ${ }^{4}$ Takatoshi Higuchi, ${ }^{5}$ \\ Aya Takeuchi, ${ }^{5}$ Kenta Serizawa, ${ }^{5}$ Tatsufumi Okino, ${ }^{6}$ and Katsumi Tsukamoto ${ }^{1}$ \\ ${ }^{1}$ Department of Marine Science and Resources, College of Bioresource Sciences, Nihon University, 1866 Kameino, Fujisawa, \\ Kanagawa 252-0880, Japan \\ ${ }^{2}$ Marine Technology and Engineering Center, Japan Agency for Marine-Earth Science and Technology, Yokosuka, \\ Kanagawa 237-0061, Japan \\ ${ }^{3}$ Department of Fisheries, Faculty of Agriculture, Kindai University, Nara 631-8505, Japan \\ ${ }^{4}$ Graduate School of Agricultural and Life Sciences, The University of Tokyo, Bunkyo, Tokyo 113-8657, Japan \\ ${ }^{5}$ Graduate School of Bioresource Sciences, Nihon University, 1866 Kameino, Fujisawa, Kanagawa 252-0880, Japan \\ ${ }^{6}$ Faculty of Environmental Earth Science, Hokkaido University, Sapporo, Hokkaido 060-0810, Japan \\ Correspondence should be addressed to Michael J. Miller; michael.miller@nihon-u.ac.jp
}

Received 18 December 2017; Revised 8 February 2018; Accepted 8 March 2018; Published 20 May 2018

Academic Editor: Nobuyuki Miyazaki

Copyright (C) 2018 Michael J. Miller et al. This is an open access article distributed under the Creative Commons Attribution License, which permits unrestricted use, distribution, and reproduction in any medium, provided the original work is properly cited.

\begin{abstract}
The circumglobal deep-sea gelatinous giant octopod, Haliphron atlanticus, reaches $4 \mathrm{~m}$ in length and uses both benthic and pelagic habitats in the upper $3000 \mathrm{~m}$ of the ocean during different life history stages, but it is rarely observed due to the deep-depths where it typically lives. It has been collected in trawls and observed a few times near continental margins or islands and has been identified in the stomach contents of deep-diving predators such as sperm whales and blue sharks or detected as body fragments after predation events. An individual $H$. atlanticus ( $1 \mathrm{~m}$ in total length) was video-recorded at 12:21 for about 3 minutes in front of the Shinkai 6500 submersible at $586-599 \mathrm{~m}\left(6.5^{\circ} \mathrm{C}\right.$, salinity 34.4$)$ along the West Mariana Ridge. It made no escape attempt as the submersible approached and it moved slowly up or down in front of the submersible. It was over the outer seamount-slope (bottom depth $\sim 3208 \mathrm{~m}$ ) 50 km west of seamounts ( $\geq 1529 \mathrm{~m}$ summits), but how it fits into the mesopelagic food web along the ridge is unclear. More information is needed to understand the role of $H$. atlanticus in oceanic food webs and if it typically lives along seamount ridges.
\end{abstract}

\section{Introduction}

Cephalopod mollusks live from nearshore to the continental slope and into the deep benthic and pelagic zones, with many of the more than 800 cephalopod species being commercially harvested [1-5]. Some are present in coastal habitats but most are found in deeper benthic habitats or pelagic zones where some squid species use diel vertical migration to deeper daytime depths, while others continuously remain at deeper depths [6].

Octopus and octopod species are separated into two major groups (sirrate: only deep-sea species; asirrate: mostly benthic) that live from nearshore to the outer continental shelf and slope, including around hydrothermal vents, whereas others live in pelagic habitats [7-9]. Deep-sea species can be collected by bottom trawling [10-12] and pelagic trawling near continental margins, islands, or seamounts [1317]. Some deep-sea squid and octopods have been observed using underwater vehicles, which has provided behavioral and life history information [8, 18-23].

Although most acirrate species tend to be associated with benthic habitats, one deep-sea species, the circumglobal gelatinous giant octopod, Haliphron atlanticus Steenstrup, 1861, (formerly named Alloposus mollis and referred to as the 
seven-arm octopus) of the family Alloposidae is somewhat unique in using both continental slope benthic habitats and open-ocean mesopelagic and bathypelagic habitats around the world, except at the extreme polar latitudes $[9,24]$. This semigelatinous species can reach 4 meters in total body length (TL) and weigh up to $75 \mathrm{~kg}$ [25] and has been caught in trawls pelagically or on the bottom at depths of about $100-3000 \mathrm{~m}$ [9]. Specimens of larger $H$. atlanticus are rare, but their presence has been reported from trawl captures, predator stomach contents (see below), or from body fragments of large individuals that have likely been preyed upon $[26,27]$. It may not be a particularly rare species though because it may be able to frequently avoid capture by nets [26].

Haliphron atlanticus is likely widely present in many areas based on its reported occurrences $[26,27]$, which also include collections in marginal sea areas such as the Banda Sea in Indonesia [10], Japan Sea [28, 29], South China Sea [30], and Gulf of Mexico [16]. Its detection in the stomach contents of some kinds of large predators also suggests it has a widespread presence.

It is typically present in small numbers in the stomach contents of sperm whales, Physeter macrocephalus [31-34], blue sharks, Prionace glauca [35-38], occasionally some tunas $[39,40]$, and lancetfish, Alepisaurus ferox [40, 41]. It is also apparently scavenged at the surface by seabirds [42-44].

Haliphron atlanticus has been video-recorded a few times by submersible or remote operated vehicles (ROV) in Monterey Bay $(390,520 \mathrm{~m})$ and along the slope at Hawaii $(250 \mathrm{~m})$ [23]. A female was seen near the bottom at $270 \mathrm{~m}$ at Hawaii [14] and small individuals have been observed to be holding jellyfish in their mouths in both pelagic and shallow waters $[23,45]$. No large individuals have been reported to be seen in deep-pelagic waters away from continental margins or islands however.

We evaluate what is known about the basic ecology of $H$. atlanticus and report an encounter with an $\sim 1 \mathrm{~m}$ total length individual at a depth of about $590 \mathrm{~m}$ over a $>3200 \mathrm{~m}$ bottom depth during a mid-water survey by the Shinkai 6500 submersible to observe spawning Japanese eels, Anguilla japonica, along the West Mariana Ridge in the western North Pacific where previous underwater survey efforts were conducted [46-49]. The $H$. atlanticus remained in front of the submersible for several minutes, allowing what appears to be the first video recording to be made of an individual of this size in the offshore mesopelagic zone. The objective of this paper is to report this observation in the context of the environment along the ridge and to consider how this circumglobal species may fit into the food webs of the mesopelagic environments where the larger individuals appear to feed.

\section{Materials and Methods}

The YK17-10 research cruise (13-27 May 2017) of the R/V Yokosuka of the Japan Agency for Marine-Earth Science and Technology (JAMSTEC) was designed to search for and video-record anguillid eels underwater in their spawning area at the West Mariana Ridge. The manned Shinkai 6500
Submersible of JAMSTEC was used to survey depths of 400-1000 m where eels might be during the daytime, based on the swimming depth data of pop-up tag studies on Japanese eels (Higuchi et al., unpublished manuscript). A multicamera towed observation system (Yokosuka Deep-Tow System; YKDT) was deployed mostly at 200-250 m where eels may be at night. Five dives were made by the Shinkai 6500 during the day and 5 deployments of the YKDT were made at night. The submersible had 2 high-definition (HD) video cameras and a camera for photographs, and the YKDT had 3 video cameras and one camera for photographs. Both systems had multiple metal halide lights, and a rectangular panel of gill netting was attached to the lower part of the front-area of the submersible. Live high-resolution YKDT video feeds were watched onboard that were transmitted through the towing cable and the environment outside the submersible was observed through 3 small port-hole windows $(12 \mathrm{~cm}$ inner-diameters) or onboard video monitors while scientists on the ship watched low-resolution acoustic video-image feeds from the submersible.

The location of the survey area was decided by first making a transect of hydrographic stations from $12.5-17^{\circ} \mathrm{N}$ along the east side of the West Mariana Ridge (see [50] Tsukamoto et al. 2011 for a map of the whole seamount ridge) using expendable conductivity, temperature, and depth profiler probes (X-CTD; Tsurumi-Seiki Co., LTD). Then a shorter transect was made on the west side of the southern part of the ridge $\left(11.5-14^{\circ} \mathrm{N}\right)$. Based on the salinity front structure and other factors, a small area along the west side of the ridge at about $14^{\circ} \mathrm{N}, 142^{\circ} \mathrm{E}$ (Figures $1(\mathrm{a})$ and $1(\mathrm{~b})$ ) was selected for intensive 24-hr observations over six days in an area where Japanese eel eggs were previously collected in June 2011 [51].

The 5 Shinkai 6500 deployments were designed to be made from 4 directions diagonally across the square-shaped survey area, with Dive 3 being only in a small area at the center (Figure 1(e)). Dives 1 and 2 (Shinkai 6500 dives \#1492 and 1493) went directly down to $1000 \mathrm{~m}$ and then followed a temperature range of $4.7-5.2^{\circ} \mathrm{C}$ while moving along a transect line before returning to the surface (Figure 2). Dive 3 (\#1494) went directly down to $917 \mathrm{~m}$ and then moved concentrically upward within a small area. Dive 4 (\#1495) went down to $1000 \mathrm{~m}$ and then moved upward by moving horizontally for short periods at 8 depths at $50 \mathrm{~m}$ intervals. The final Dive 5 (\#1496) first surveyed at $400 \mathrm{~m}$ for almost 2 hours and then went down to $1000 \mathrm{~m}$ before moving up to $400 \mathrm{~m}$, down to almost $800 \mathrm{~m}$, and then to the surface. All YKDT nighttime deployments were similar and mostly surveyed in the narrow target depth layer by moving up and down within the designated depth layer while being towed along each transect, but these data are not included in the present paper because no $H$. atlanticus were detected.

To examine the location where the octopod was seen in relation to the structure of the West Mariana Ridge [52], two vertical bathymetric sections were plotted (Figures 1(b), $1(\mathrm{c})$, and $1(\mathrm{~d})$ ) from the global bathymetry gridded SRTM 15 Plus dataset (http://topex.ucsd.edu/WWW_html/srtm30_ plus.html) using the Generic Mapping Tools 4 (GMT) program (https://www.soest.hawaii.edu/gmt/). 

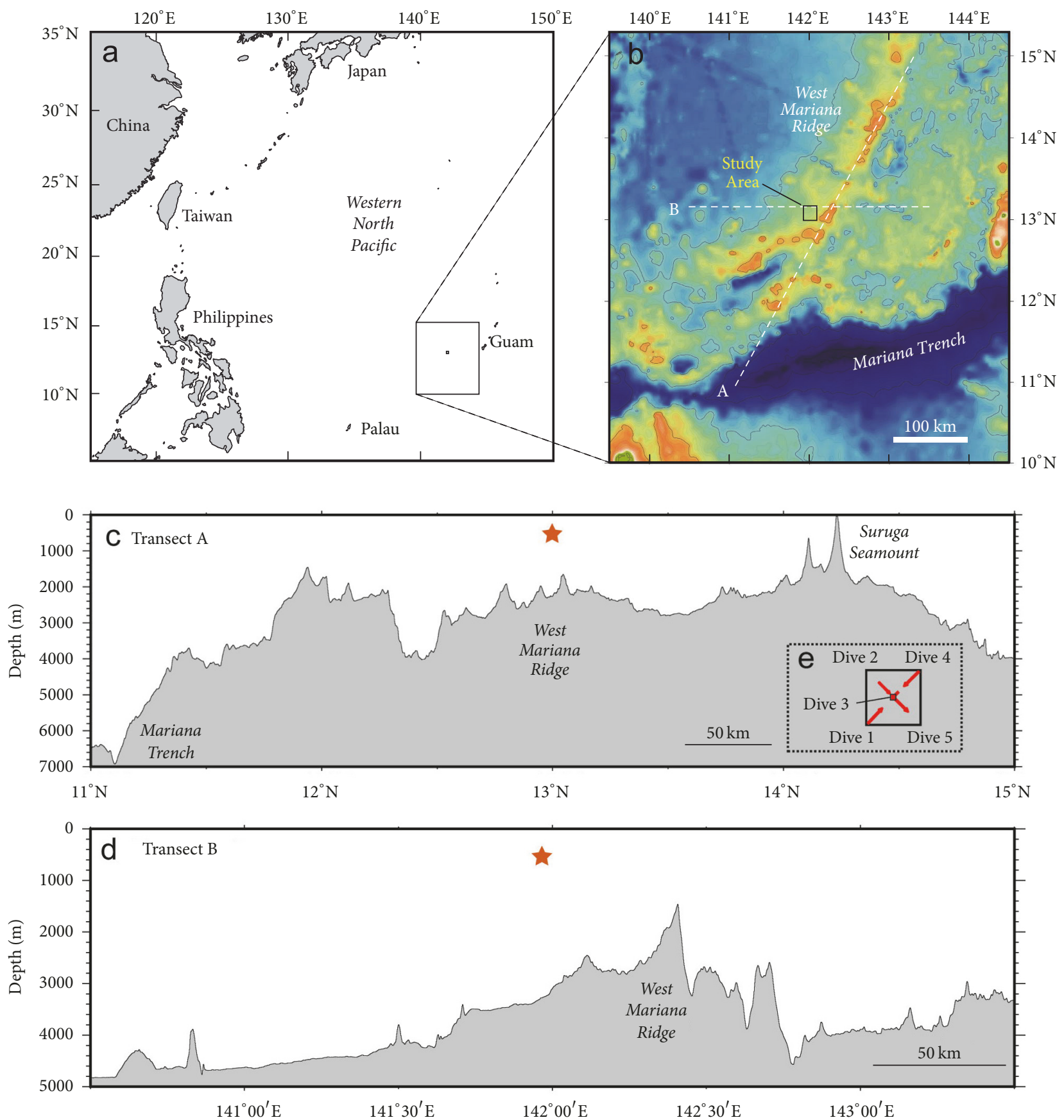

FIgURE 1: Location of the YK17-10 study area in the western North Pacific (a), the bottom topography of the southern West Mariana Ridge and Mariana Trench region showing the study area where underwater observations by the Shinkai 6500 submersible were made (small squares in $(a, b)$ ) along the west side of the ridge (b), and vertical profiles of bottom depth along transects (dashed lines in (b)) extending from the trench northward along the ridge ( $\mathrm{c}$; Transect $\mathrm{A}$ ) and crossing the ridge longitudinally along the northern edge of the study area that includes the shallowest seamount in that part of the ridge (d; Transect B), with the location where the gelatinous giant octopod, Haliphron atlanticus, was seen, shown with stars. A diagram of the approximate horizontal directions and locations of the dive tracks of the submersible inside the study area square is shown in the inset (d). Color in (b) indicates deeper (blue/dark) and shallower (yellow-orange/lighter) depths.

Only some male $H$. atlanticus appear to have seven arms, so we follow the recent FAO common name of "gelatinous giant octopod" [9]. The individual $H$. atlanticus we observed was identified to species based on identification guides $[9,26]$ and its similarity to previous video observations of similarly sized individuals (see Discussion).

\section{Results}

A variety of planktonic organisms including crustaceans, gelatinous zooplankton, and mostly small fishes were observed during the 5 Shinkai 6500 dives. During Dive 3 on 22 May, a large object was seen in the distance at 12:21 at $599 \mathrm{~m}$ 


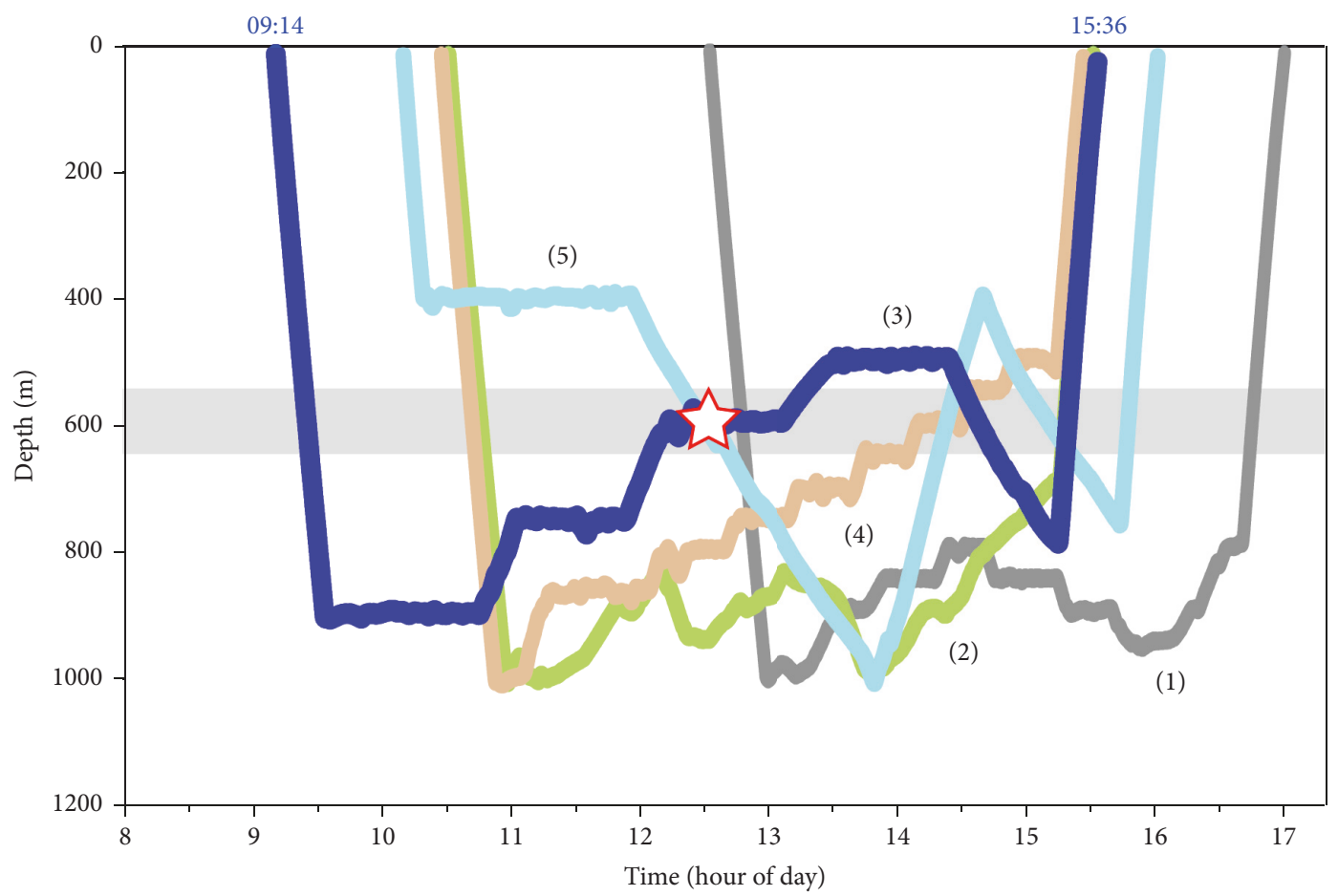

Figure 2: Time-depth plots of the 5 Shinkai 6500 submersible dives made during the YK17-10 underwater survey near the southern West Mariana Ridge in May 2017. The star shows the location when the gelatinous giant octopod, Haliphron atlanticus, was seen and the shaded area shows the general depth layer where the octopus was seen for evaluating how much observation effort occurred at that zone during the submersible dives.

(Figure 2), over a bottom depth of $\sim 3298 \mathrm{~m}$ at $13^{\circ} 05^{\prime} 07 \mathrm{~N}$, $141^{\circ} 59^{\prime} 97 \mathrm{E}$ and the submersible slowly stopped to observe an orange-brown colored gelatinous giant octopod as it emerged into full view (Video S1). This resulted in it being videorecorded for $2 \mathrm{~min}$ and $47 \mathrm{sec}$ (Figure 3; Videos S1 and S2). Comparing to the size of the gillnet frame on the front of the submersible, the octopod appeared to be slightly larger than $1 \mathrm{~m}$ in total length (TL).

The clear view of the octopod (Figure 3; Video S2) enabled it to be identified as $H$. atlanticus, even though most morphological descriptions and illustrations of this species are for smaller individuals that have somewhat different body forms $[9,26]$. It had a short mantle, a large funnel on the ventral midline, 2 long arms, 2 medium-length arms, and 4 shorter arms, which is consistent with this species at various sizes $[9,23,24]$.

The observation point was over the ridge slope about $50 \mathrm{~km}$ from seamounts, with the nearest and tallest seamount having a summit at about $1470 \mathrm{~m}$ from the surface (Figures $1(\mathrm{c})$ and $1(\mathrm{~d}))$. The $H$. atlanticus was initially observed at $599 \mathrm{~m}$ where it was $6.5^{\circ} \mathrm{C}$, with a salinity of 34.4 and a density (sigma- $t$ ) of $27.0 \mathrm{~kg} \mathrm{~m}^{-3}$ (Figure 4 ). The octopod was weakly moving upward even though it appeared stationary in the video recordings because the submersible was also moving upward. After almost $3 \mathrm{~min}$ a depth of $586 \mathrm{~m}$ was reached. The temperature had changed to $6.6^{\circ} \mathrm{C}$, but the salinity and density were still the same. Examination of the hydrographic data collected by the submersible and comparison to the hydrographic sections plotted from 5 X-CTD deployments crossing through the study area indicated that it was in a zone with very gradual temperature decreases with depth and minimal salinity changes (34.4 from $\sim 300-800 \mathrm{~m}$ ) below the high-salinity layer of Subtropical Underwater (STUW), which is a typical feature of this area (see [53]) (Figure 4). The latitude of the observation was within the main part of the westward flow of the North Equatorial Current $[54,55]$.

The lack of any obvious escape response of the $H$. atlanticus enabled its behavior to be recorded by both of the HD video cameras (Videos S1 and S2). The octopus was obliquely facing upward as the submersible slowly moved towards it. Then it was closer to the front of the submersible while being brightly illuminated by the lights. It initially remained in a vertically oriented body position at a slight angle while slowly moving upward about a meter in front of the submersible. It then shifted back and forth between horizontal-vertical and forward-sideways orientations while moving to higher or lower levels due to weak movements. Then it moved downwards with the front of its mantle lightly touching the frame of the gill net in front of the submersible as it moved out of sight.

\section{Discussion}

Our underwater observation of an approximately 1-m gelatinous giant octopod, $H$. atlanticus, during the day at about $590 \mathrm{~m}$ along the West Mariana Ridge in the proximity of seamounts appears to be unique regarding the size of the individual and its location near a seamount ridge. 

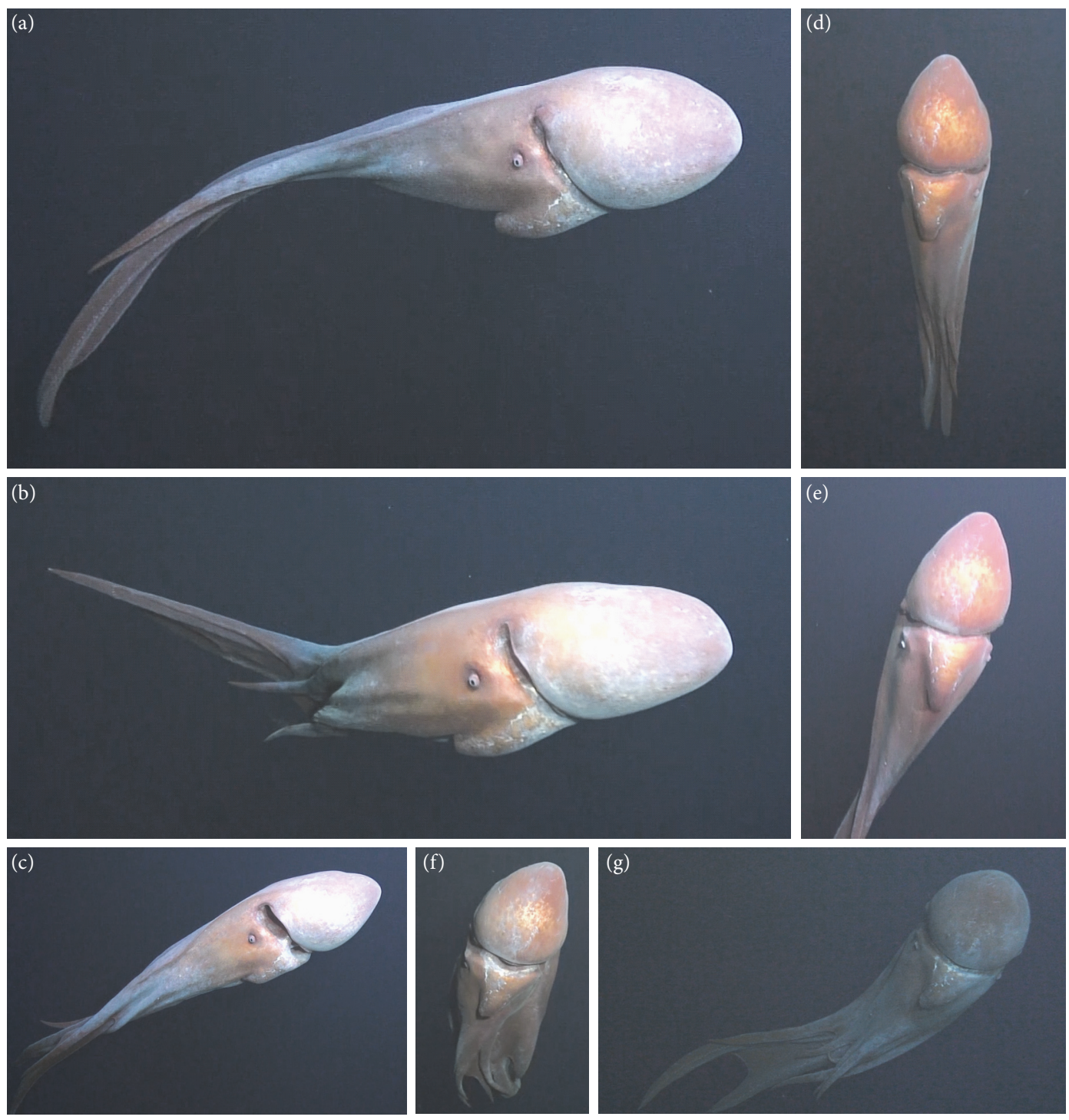

FIGURE 3: Video frame-captures of a gelatinous giant octopod, Haliphron atlanticus, that was video-recorded in front of the Shinkai 6500 submersible at about 586-599 m along the West Mariana Ridge in May 2017 showing various different postures and orientations near the end of the encounter (a) 12:24:22, $589 \mathrm{~m}$, (b) 12:24:26, $588 \mathrm{~m}$, and (c) 12:24:18, $589 \mathrm{~m}$, and earlier in the encounter (d) 12:22:20, 598 m, (e) 12:22:32, $598 \mathrm{~m}$, (f) $12: 23: 37,591 \mathrm{~m}$, and (g) 12:23:18, $594 \mathrm{~m}$.

Haliphron atlanticus females $(\leq 4 \mathrm{~m} \mathrm{TL})$ are much larger than the males $(\sim 210 \mathrm{~mm} \mathrm{TL})[9,24]$, so the individual we observed must have been a female. Smaller individuals have more similar arm lengths and appear more compact in proportions, with a large mantle and shorter arms $[9,24,26]$ compared to the individual we observed. Its color and morphological features were quite similar to a previous video recording of a $H$. atlanticus followed by a submersible near the bottom at $396 \mathrm{~m}$ at Hawaii (https://www.youtube.com/ watch?v=Aer0uustNC4; accessed 24 July 2017). That $H$. atlanticus observed at Hawaii actively swam away from the submersible, as did another smaller and damaged individual [14] that was recorded at Hawaii at $270 \mathrm{~m}$ (https://www .youtube.com/watch? $\mathrm{v}=$ FpjiGbVqWws; accessed 24 July 2017). However, those individuals could have been at the bottom for reproduction. The Monterey Bay Aquarium
Research Institute (MBARI) has observed small individuals of this species 3 times in 27 years by ROV, which were in the Monterey Submarine Canyon (two observations at 390 and $520 \mathrm{~m}$ ) and off Hawaii $(250 \mathrm{~m})$ [23].

In one MBARI video, the octopus does not seem to try to escape but opens its arms to reveal that it had an apparently live jellyfish fitted perfectly over its mouth area (https://www.youtube.com/watch? $\mathrm{v}=\mathrm{CzU} 8 \mathrm{CUXxLsA}$; accessed 24 July 2017). This behavior is similar to another small $H$. atlanticus that was video-recorded protruding a jellyfish in its mouth towards a diver, suggesting use of the jellyfish as a defensive posture [45]. Hoving and Haddock [23] provide evidence that this species may feed on gelatinous zooplankton, but crustaceans have also been found in their stomach contents [56]. The strange behavior of holding jellyfish may suggest complex interactions between 


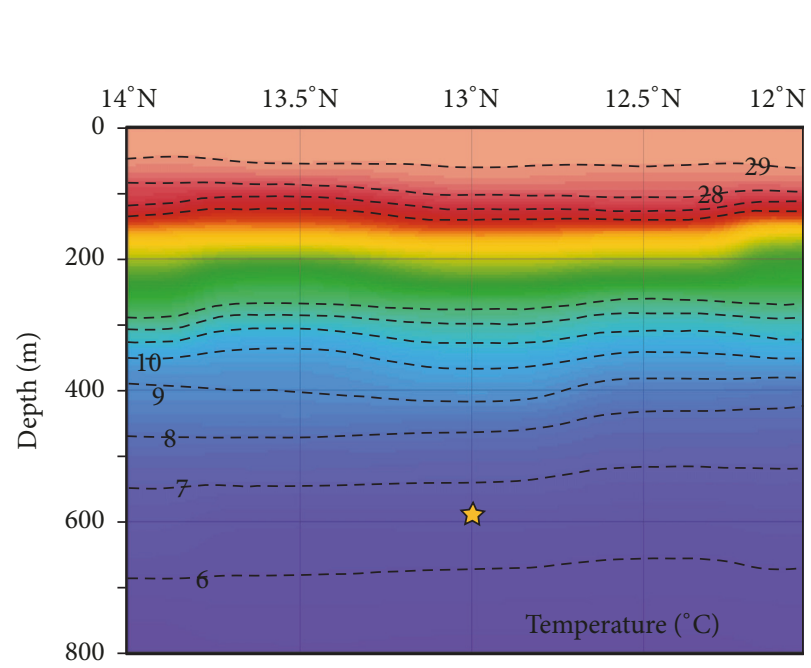

(a)

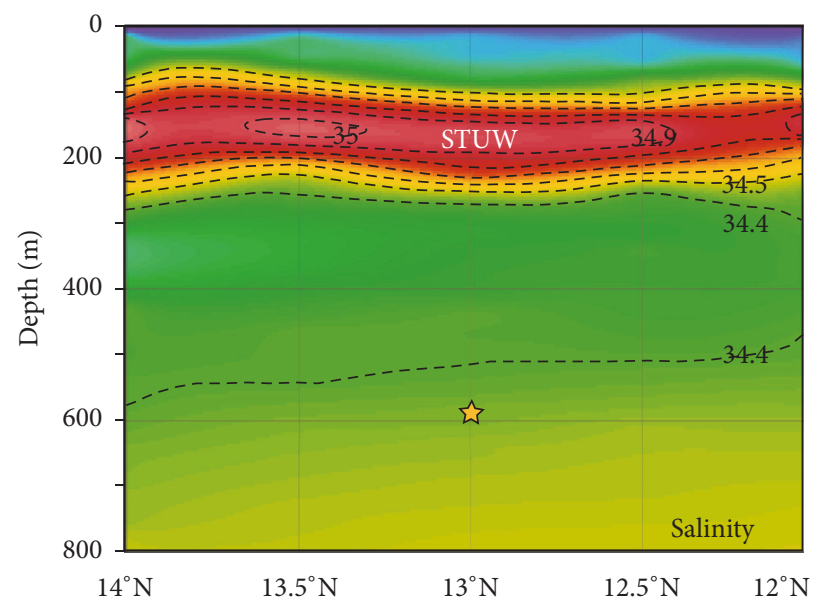

(c)

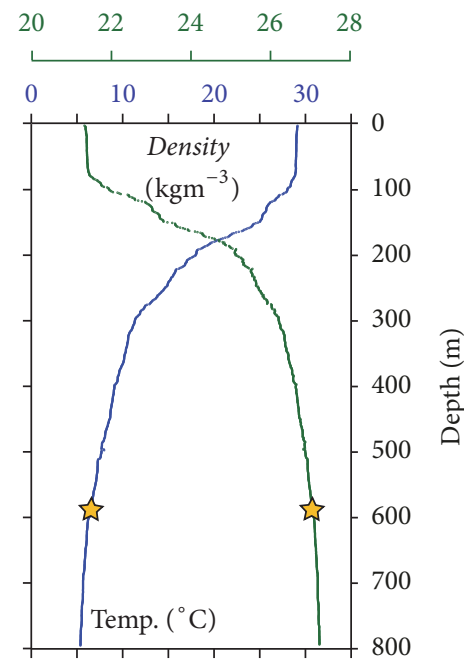

(b)

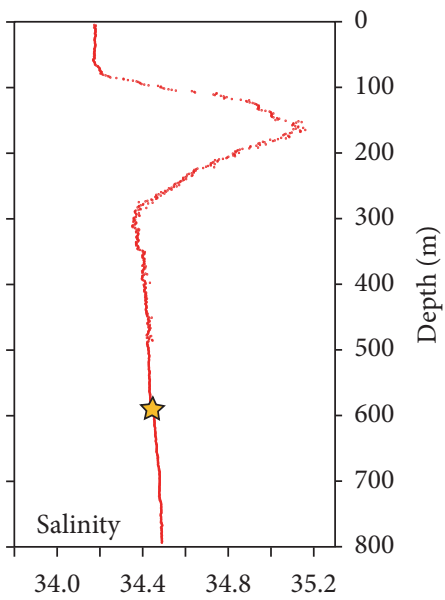

(d)

FIGURE 4: Hydrographic characteristics in the upper $800 \mathrm{~m}$ in vertical sections plotted from X-CTD data (a, b), and temperature, density, and salinity profiles plotted from data obtained from the CTD onboard the Shinkai 6500 submersible during the dive (c, d) when a $\sim 1 \mathrm{~m}$ Haliphron atlanticus was video-recorded at depths from 586 to $599 \mathrm{~m}$. The approximate depth/latitude location where the octopus was seen is marked by stars for each parameter. In (a) only isotherm contours mostly outside the thermocline are shown, and in (b) only isohalines mostly associated with the high-salinity Subtropical Underwater (STUW) are shown.

the two types of species, because similar interactions [57] have been observed in other cephalopods. Stable isotope analyses suggest $H$. atlanticus has an intermediate trophic level compared to other cephalopods $[58,59]$, which could be consistent with feeding on gelatinous zooplankton and other types of prey.

Our observation of $H$. atlanticus over the western slope of the West Mariana Ridge suggests that these seamount ridge habitats can be used by this species and that they are part of the pelagic food web along the ridge. This is consistent with the concept that this species may not be entirely independent of continental slope habitats, since most observations and collection records were not far from continental shelves or islands [9, 26, 27] or were near a seamount [17] or an ocean ridge [60]. The West Mariana Ridge has a variety of seamounts along the ridge, with some reaching $<200 \mathrm{~m}$ and a few being near the surface (Figure $1(\mathrm{c})$ ), and this pattern extends to the north along the ridge [52]. Body parts of $H$. atlanticus have been observed farther north along these ridge systems around the Ogasawara Islands south of Japan (T. $\mathrm{Wu}$ personal communication) where sperm whales actively feed [61, 62] on species such as giant squid, Architeuthis, and possibly eight-armed squid, Taningia danae, which have been observed there $[63,64]$. Haliphron atlanticus has also been reported from Sagami Bay of eastern Japan [65] (as cited by [26]). This suggests that $H$. atlanticus may be widely distributed in the western North Pacific, at least along continental margins, and near seamount ridges or islands.

In the northwestern Atlantic, it was collected in 35\% of 175 mid-water tows and $16 \%$ of 56 bottom trawls on or around the Bear Seamount (1100 m summit) near the continental margin at sizes of $17-115 \mathrm{~mm}$ (mantle length, ML) in a recent study of the biodiversity of cephalopods at the seamount $(N=$ 195; [17]). A few were also collected along the Mid-Atlantic 
Ridge in the North Atlantic [60]. Haliphron atlanticus was also present in the mid-water off of the continental margin of the Gulf of Mexico at sizes of 3-235 mm ML ( $N=46$; [16])

It is unclear though how abundant this species may be in various areas around the world and along the ridges in the western North Pacific. We have made a variety of sampling and underwater observation efforts along the West Mariana Ridge, but most of our observation surveys and net sampling have been at shallower depths than the $590 \mathrm{~m}$ where we observed $H$. atlanticus in the present study. The 4 other 2017 dives spent minimal time at that depth layer, but they did pass through it several times (Figure 2). Three 2012 daytime Shinkai 6500 dives passed through the 590-m layer multiple times, but no $H$. atlanticus were detected [46]. Various pelagic fishes and invertebrates (zooplankton, jellyfish, siphonophores, crustaceans, and polychaetes) have been seen along the ridge, including mesopelagic fishes, freckled driftish, Psenes cyanophrys, scombrids (juveniles and a large tuna), a thresher shark, Alopias pelagicus, a possible blue shark, and squid, Sthenoteuthis oualaniensis and Onychoteuthis $[46,48,49]$. Mesopelagic eels of the Derichthyidae, Eurypharyngidae, Nemichthyidae, and Serrivomeridae are present in this area because they have been seen by underwater camera systems or collected as small larvae $[47,49,66]$. In addition, long-thin eels (likely Serrivomeridae) with their bodies in a rigid vertical position were observed in the present study at depths up to $850 \mathrm{~m}$, and this behavior was also observed from the submersible in 2012 [47]. Zooplankton were abundant at the location where the $H$. atlanticus was seen in the present study (Video S1).

Although the feeding ecology of $H$. atlanticus in mesopelagic environments such as along seamount ridges is not understood yet, they are eaten by some large predator species based on food habits studies. What feeds on it may be related to the depth range where $H$. atlanticus lives, because it appears to be most commonly detected in deep-foraging sperm whales and blue shark diets. It has been reported in the stomach contents of sperm whales in the northeastern Atlantic North Sea region [32], the eastern Atlantic Canary Islands [34], southern Australia [33], and Patagonia of South America [31]. In one case $38 \mathrm{H}$. atlanticus were the main prey by weight in a whale in the northeast Atlantic [67]. These toothed whales dive down to various deep-depths and feed mostly on squid and fishes using acoustic echolocation hunting techniques $[61,62,68,69]$, including at the depth where the $H$. atlanticus was seen in the present study. Incomplete predation events by sperm whales on these gelatinous octopods may be how the body parts of large individuals that have been found are produced [27].

Haliphron atlanticus is also typically present in small to moderate numbers in the stomach contents of blue sharks, such as near the Azores in the North Atlantic [35], off California [38] and Brazil [37], and in the Kuroshio Extension [36], but it is not present in the diets of some other shark species $[36,38]$ and is not always found in blue shark stomach contents [70]. Blue sharks are the most abundant sharks in some parts of the world, reaching $3 \mathrm{~m}$ in length, and they typically feed mostly on squid, fishes, and crustaceans [70, 71]. Blue sharks move widely in areas such as the North
Atlantic [72] and are distributed offshore in about the upper $350 \mathrm{~m}$ during daytime and at deeper depths at night (mostly 400-770 m) [71, 73-75]. Therefore, their foraging depths can directly overlap with the depth where the $H$. atlanticus was seen in the present study and where smaller individuals live [13].

It may be typically absent in most large predatory fish stomach contents (literature reviewed by [76]), but a few individuals were eaten by dolphinfish, Coryphaena hippurus [77], bigeye tuna, Thunnus obesus [39], yellowfin tuna, Thunnus albacares [40], albacore, Thunnus alalunga [40], swordfish, Xiphias gladius [40, 78], and lancetfish [40, 41]. But they are typically absent in the stomach contents of these types of fish predator diets $[79,80]$.

Haliphron atlanticus has been detected in the diets of the Hawaiian monk seal, Monachus schauinslandi [81], and South Shetland Island Weddell seals, Leptonychotes weddellii [82], and it may be scavenged at the surface by seabirds after predation events by large predators. It has been detected in South Atlantic albatross [43, 44], Azores Cory's shearwater, Calonectris diomedea [42], and Monterey Bay California Pacific northern fulmar, Fulmarus glacialis rogersii [83] diets. It appears unlikely however that the seabirds are actually preying on this species and are more likely scavenging body parts or dead individuals, as discussed previously $[84,85]$.

Our observation of an $\sim 1 \mathrm{~m} \mathrm{H}$. atlanticus along the West Mariana Ridge, previous collection records, and its presence in deep-diving predator stomach contents as briefly overviewed here illustrate the widespread presence of this species in pelagic waters along continental margins, around islands, seamounts, or ridges, and in marginal seas. Although our observation does not provide answers to the many interesting questions about this species, such as which pelagic animals it may feed on and how they may use jellyfish $[23,45]$, it does provide an intimate visual view of a species that can grow at least about 3 times larger than the individual we observed. Reproduction probably occurs intermittently on the continental slope $[9,14]$, and it could be more abundant than indicated by existing information if larger $\mathrm{H}$. atlanticus are well adapted for avoiding trawls [26], which is the case for various types of pelagic organisms [86]. Morphological and genetic information suggests this species may consist of two different geographically separated species [4, 25, 27]. Therefore, the phylogeography, biology, and life history of $H$. atlanticus require further research using a variety of methodologies $[4,87]$ to obtain more information about these large semigelatinous octopods that are found around the world.

\section{Conclusions}

The observation of a 1-m individual of the circumglobal deepsea gelatinous giant octopod, Haliphron atlanticus, above the western slope of the West Mariana Ridge provided a unique close-up view of this species in the mesopelagic zone. The lack of any escape response allowed it to be seen clearly and video-recorded. This species has been collected at small sizes in pelagic trawls near continental shelves or seamounts, but larger individuals can likely usually avoid being captured 
by trawls. It is sometimes eaten by deep-diving predators such as sperm whales and blue sharks that prey on large squid, but its role in food webs and its actual abundance are uncertain. The ecology of this species in continental shelf or slope habitats where they reproduce and pelagic environments where they feed needs further exploration before this mysterious deep-sea octopod that can reach at least $4 \mathrm{~m}$ can be fully understood.

\section{Conflicts of Interest}

The authors declare that they have no conflicts of interest.

\section{Acknowledgments}

The authors thank the Shinkai 6500 submersible and DeepTow teams for their intensive efforts and support during this survey and the captain and crew of the R/V Yokosuka for their assistance. They also thank S. Oshitani and T. Nasu for technical support during the survey. The support of the JAMSTEC cruise administration team is also greatly appreciated.

\section{Supplementary Materials}

Supplementary 1. Supplementary Video 1: video imagery recorded by Camera 1 of the Shinkai 6500 submersible showing a seven-arm octopus, Haliphron atlanticus, as it was first seen in the distance and as it was in front of the submersible at depths of 586-599 m over the outer slope of the West Mariana Ridge at 12:21 on 22 May 2017.

Supplementary 2. Supplementary Video 2: video imagery recorded by Camera 2 of the Shinkai 6500 submersible showing a seven-arm octopus, Haliphron atlanticus, in front of the submersible at depths of 586-599 m over the outer slope of the West Mariana Ridge on 22 May 2017.

\section{References}

[1] M. R. Clarke, “The role of cephalopods in the world's oceans: General conclusions and the future," Philosophical Transactions of the Royal Society B: Biological Sciences, vol. 351, no. 1343, pp. 1105-1112, 1996.

[2] M. C. Dunning, M. D. Norman, and A. L. Reid, "Cephalopods," in FAO Species Identification Guide for Fishery Purposes. The Living Marine Resources of The Western Central Pacific. Volume 2. Cephalopods, Crustaceans, Holothurians And Sharks, K. E. Carpenter and V. H. Niem, Eds., pp. 687-1396, FAO, Rome, Italy, 1998.

[3] P. Jereb and C. F. E. Roper, "Cephalopods of the world. An annotated and illustrated catalogue of cephalopod species known to date," in FAO Species Catalogue for Fishery Purposes, no. 4, vol. 3. Volume 2: Myopsid and Oegopsid Squids, P. Jereb and C. F. E. Roper, Eds., FAO, Rome, Italy, 2010.

[4] H.-J. T. Hoving, J. A. A. Perez, K. S. R. Bolstad et al., "The study of deep-sea cephalopods," Advances in Marine Biology, vol. 67, pp. 235-359, 2014.

[5] P. Jereb, C. F. E. Roper, M. D. Norman, and J. K. Finn, "Cephalopods of the world. An annotated and illustrated catalogue of cephalopod species known to date," in FAO Species Catalogue for Fishery Purposes, No. 4, vol. 3. Volume 3: Octopods and Vampire Squids, P. Jereb, C. F. E. Roper, M. D. Norman, and J. K. Finn, Eds., FAO, Rome, Italy, 2016.

[6] H. Watanabe, T. Kubodera, M. Moku, and K. Kawaguchi, "Diel vertical migration of squid in the warm core ring and cold water masses in the transition region of the western North Pacific," Marine Ecology Progress Series, vol. 315, pp. 187-197, 2006.

[7] F. Rocha, Á. F. González, M. Segonzac, and Á. Guerra, "Behavioural observations of the cephalopod Vulcanoctopus hydrothermalis," Cahiers de Biologie Marine, vol. 43, no. 3-4, pp. 299-302, 2002.

[8] J. R. Voight, "Observations of deep-sea octopodid behavior from undersea vehicles," American Malacological Bulletin, vol. 24, no. 1-2, pp. 43-50, 2008.

[9] J. K. Finn, "Family Alloposidae. Cephalopods of the world. An annotated and illustrated catalogue of cephalopod species known to date," in FAO Species Catalogue for Fishery Purposes, No. 4, vol. 3. Volume 3: Octopods and Vampire Squids, P. Jereb, C. F. E. Roper, M. D. Norman, and J. K. Finn, Eds., pp. 225-228, FAO, Rome, Italy, 2016.

[10] M. D. Norman, F. G. Hochberg, and C. C. Lu, "Mollusca Cephalopoda: Mid-depth octopuses (200-1000 m) of the Banda and Arafura Seas (Octopodidae and Alloposidae)," in Résultats des Campagnes MUSORSTOM, vol. 16, Mémoires du Muséum National d'Histoire Naturelle, A. Crosnier and P. Bouchet, Eds., vol. 172, pp. 57-383, 1997.

[11] T. Bakken and T. Holthe, "Haliphron atlanticum (Cephalopoda, Alloposidae) caught in Skjørafjorden $\left(64^{\circ} \mathrm{N}\right)$, Norway," Fauna Norvegica, vol. 22, pp. 37-38, 2002.

[12] R. Rosa, J. Pereira, and A. Moreno, "Bathymetric range, density and reproductive biology of the deep-sea cirrate octopus Opisthoteuthis calypso in the Portuguese continental slope," Journal of the Marine Biological Association of the United Kingdom, vol. 89, no. 1, pp. 131-134, 2009.

[13] C. F. Roper and R. E. Young, "Vertical distribution of pelagic cephalopods," Smithsonian Contributions to Zoology, no. 209, pp. 1-51, 1975.

[14] R. E. Young, "Aspects of the natural history of pelagic cephalopods of the Hawaiian mesopelagic-boundary region," Pacific Science, vol. 49, no. 2, pp. 143-155, 1995.

[15] M. Vecchione and G. Pohle, "Midwater cephalopods in the western North Atlantic Ocean off Nova Scotia," Bulletin of Marine Science, vol. 71, no. 2, pp. 883-892, 2002.

[16] H. Judkins, M. Vecchione, A. Cook, and T. Sutton, "Diversity of midwater cephalopods in the northern Gulf of Mexico: comparison of two collecting methods," Marine Biodiversity, vol. 47, no. 3, pp. 647-657, 2017.

[17] E. K. Shea, H. Judkins, M. D. Staudinger, V. H. Dimkovikj, A. Lindgren, and M. Vecchione, "Cephalopod biodiversity in the vicinity of Bear Seamount, western North Atlantic based on exploratory trawling from 2000 to 2014," Marine Biodiversity, vol. 47, no. 3, pp. 699-722, 2017.

[18] M. Vecchione and C. F. E. Roper, "Cephalopods observed from submersibles in the Western North Atlantic," Bulletin of Marine Science, vol. 49, pp. 433-445, 1991.

[19] R. Villanueva, M. Segonzac, and A. Guerra, "Locomotion modes of deep-sea cirrate octopods (Cephalopoda) based on observations from video recordings on the Mid-Atlantic ridge," Marine Biology, vol. 129, no. 1, pp. 113-122, 1997.

[20] M. Vecchione, C. F. E. Roper, E. A. Widder, and T. M. Frank, "In situ observations on three species of large-finned deep-sea 
squids," Bulletin of Marine Science, vol. 71, no. 2, pp. 893-901, 2002.

[21] J. C. Drazen, S. K. Goffredi, B. Schlining, and D. S. Stakes, "Aggregations of egg-brooding deep-sea fish and cephalopods on the gorda escarpment: A reproductive hot spot," The Biological Bulletin, vol. 205, no. 1, pp. 1-7, 2003.

[22] B. Robison, B. Seibel, and J. Drazen, "Deep-sea octopus (Graneledone boreopacifica) conducts the longest-known eggbrooding period of any animal," PLoS ONE, vol. 9, no. 7, Article ID e103437, 2014.

[23] H. J. T. Hoving and S. H. D. Haddock, "The giant deepsea octopus Haliphron atlanticus forages on gelatinous fauna," Scientific Reports, vol. 7, Article ID 44952, 2017.

[24] R. E. Young, Alloposidae Verrill 1881. Haliphron atlanticus Steenstrup 1861, Version 16 November 2016 (under construction). http://tolweb.org/Haliphron_atlanticus/20200/2016.11.16 in The Tree of Life Web Project, http://tolweb.org/, 2016. [accessed 19 July 2017].

[25] S. O'Shea, “The giant octopus Haliphron atlanticus (Mollusca: Octopoda) in New Zealand waters," New Zealand Journal of Zoology, vol. 31, no. 1, pp. 7-13, 2004.

[26] A. Alvari and J. R. Hunter, "New records of Alloposus mollis Verrill (Cephalopoda, Octopoda) from the Pacific Ocean," The Nautilus, vol. 95, pp. 26-32, 1981.

[27] F. D. Lima, L. F. Mendes, L. Veras, T. S. Leite, and S. M. Q. Lima, "The seven-arm octopus, Haliphron atlanticus streenstrup, 1861 (Cephalopoda, alloposidae), in the fernando de noronha archipelago, Brazil," Check List, vol. 13, no. 1, article no. 2036, 2017.

[28] S. Nishimura, "A preliminary list of the pelagic Cephalopoda from the Japan Sea," Publications of the Seto Marine Biological Laboratory, vol. 16, no. 1, pp. 71-83, 1968.

[29] Y. Kawakami and K. Ichisawa, "Marine animals recorded in the Sea of Japan around Tottori Prefecture from 2010 to 2011, with notes on a large specimen of Sharptail Mola collected off Sakaiminato," Bulletin of the Tottori Prefectural Museum, vol. 49, pp. 13-16, 2012.

[30] M. D. Norman, J. Nabhitabhata, and C. C. Lu, "An updated checklist of the cephalopods of the South China Sea," The Raffles Bulletin of Zoology, vol. 34, pp. 566-592, 2016.

[31] P. L. Pascoe, M. C. Mickiewicz, and H. P. Castello, "Cephalopod remains from the stomach of a sperm whale stranded off Patagonia," Marine Biology, vol. 104, no. 1, pp. 1-4, 1990.

[32] M. B. Santos, G. J. Pierce, P. R. Boyle et al., "Stomach contents of sperm whales Physeter macrocephalus stranded in the North Sea 1990-1996," Marine Ecology Progress Series, vol. 183, pp. 281-294, 1999.

[33] K. Evans and M. A. Hindell, "The diet of sperm whales (Physeter macrocephalus) in southern Australian waters," ICES Journal of Marine Science, vol. 61, no. 8, pp. 1313-1329, 2004.

[34] R. Fernández, M. B. Santos, M. Carrillo, M. Tejedor, and G. J. Pierce, "Stomach contents of cetaceans stranded in the Canary Islands 1996-2006," Journal of the Marine Biological Association of the United Kingdom, vol. 89, no. 5, pp. 873-883, 2009.

[35] M. R. Clarke, D. C. Clarke, H. R. Martins, and H. M. Da Silva, "The diet of the blue shark (Prionace bauca L.) in Azorean waters," Arquipelago. Life and Marine Sciences, vol. 14A, pp. 4156, 1996.

[36] T. Kubodera, H. Watanabe, and T. Ichii, "Feeding habits of the blue shark, Prionace glauca, and salmon shark, Lamna ditropis, in the transition region of the Western North Pacific," Reviews in Fish Biology and Fisheries, vol. 17, no. 2-3, pp. 111-124, 2007.
[37] T. Vaske Júnior, R. P. Lessa, and O. B. F. Gadig, "Feeding habits of the blue shark (Prionace glauca) off the coast of Brazil," Biota Neotropica, vol. 9, no. 3, pp. 55-60, 2009.

[38] A. Preti, C. U. Soykan, H. Dewar, R. J. D. Wells, N. Spear, and S. Kohin, "Comparative feeding ecology of shortfin mako, blue and thresher sharks in the California Current," Environmental Biology of Fishes, vol. 95, no. 1, pp. 127-146, 2012.

[39] K. Tsuchiya, H. Okamoto, and Y. Uozumi, "Cephalopods eaten by pelagic fishes in the tropical East Pacific, with special reference to the feeding habitat of pelagic fish," La mer, vol. 36, no. 2, pp. 57-66, 1998.

[40] F. Ménard, M. Potier, S. Jaquemet, E. Romanov, R. Sabatié, and Y. Cherel, "Pelagic cephalopods in the western Indian Ocean: New information from diets of top predators," Deep-Sea Research Part II: Topical Studies in Oceanography, vol. 95, pp. 83-92, 2013.

[41] M. Potier, F. Marsac, Y. Cherel et al., "Forage fauna in the diet of three large pelagic fishes (lancetfish, swordfish and yellowfin tuna) in the western equatorial Indian Ocean," Fisheries Research, vol. 83, no. 1, pp. 60-72, 2007.

[42] J. P. Granadeiro, L. R. Monteiro, and R. W. Furness, "Diet and feeding ecology of Cory's shearwater Calonectris diomedea in the Azores, north-east Atlantic," Marine Ecology Progress Series, vol. 166, pp. 267-276, 1998.

[43] F. I. Colabuono and C. M. Vooren, "Diet of black-browed Thalassarche melanophrys and atlantic yellow-nosed T. chlororhynchos albatrosses and white-chinned Procellaria aequinoctialis and spectacled P. conspicillata Petrels off southern Brazil," Marine Ornithology, vol. 35, no. 1, pp. 9-20, 2007.

[44] J. C. Xavier and J. P. Croxall, "Predator-prey interactions: Why do larger albatrosses eat bigger squid?" Journal of Zoology, vol. 271, no. 4, pp. 408-417, 2007.

[45] R. Rosa, J. T. Kelly, V. M. Lopes et al., "Deep-sea seven-arm octopus hijacks jellyfish in shallow waters," Marine Biodiversity, pp. 1-5, 2017.

[46] K. Tsukamoto, N. Mochioka, M. J. Miller, S. Koyama, S. Watanabe, and J. Aoyama, "Video observation of an eel in the Anguilla japonica spawning area along the West Mariana Ridge," Fisheries Science, vol. 79, no. 3, pp. 407-416, 2013.

[47] M. J. Miller, S. Koyama, N. Mochioka, J. Aoyama, S. Watanabe, and K. Tsukamoto, "Vertical body orientation by a snipe eel (Nemichthyidae, Anguilliformes) in the deep mesopelagic zone along the West Mariana Ridge," Marine and Freshwater Behaviour and Physiology, vol. 47, no. 4, pp. 265-272, 2014.

[48] M. J. Miller, T. Miwa, N. Mochioka et al., "Now you see me, now you don't: observation of a squid hiding in its ink trail," Marine Biodiversity, vol. 45, no. 2, pp. 149-150, 2015.

[49] T. Fukuba, T. Miwa, S. Watanabe et al., "A new drifting underwater camera system for observing spawning Japanese eels in the epipelagic zone along the West Mariana Ridge," Fisheries Science, vol. 81, no. 2, pp. 235-246, 2015.

[50] K. Tsukamoto, S. Chow, T. Otake et al., "Oceanic spawning ecology of freshwater eels in the western North Pacific," Nature Communications, vol. 2, no. 1, Article ID ncomms1174, 2011.

[51] J. Aoyama, S. Watanabe, M. J. Miller et al., "Spawning sites of the Japanese eel in relation to oceanographic structure and the West Mariana Ridge," PLoS ONE, vol. 9, no. 2, Article ID e88759, 2014.

[52] J. V. Gardner, “The West Mariana Ridge, western Pacific Ocean: Geomorphology and processes from new multibeam data," Bulletin of the Geological Society of America, vol. 122, no. 9-10, pp. 1378-1388, 2010. 
[53] R. Schabetsberger, M. J. Miller, G. Dall'Olmo et al., "Hydrographic features of anguillid spawning areas: Potential signposts for migrating eels," Marine Ecology Progress Series, vol. 554, pp. 141-155, 2016.

[54] I. Kaneko, Y. Takatsuki, H. Kamiya, and S. Kawae, "Water property and current distributions along the WHP-P9 section (137 $142^{\circ} \mathrm{E}$ ) in the western North Pacific," Journal of Geophysical Research: Oceans, vol. 103, no. 3336, pp. 12959-12984, 1998.

[55] A. C. Hsu, H. Xue, F. Chai, P. Xiu, and Y.-S. Han, "Variability of the Pacific North Equatorial Current and its implications on Japanese eel (Anguilla japonica) larval migration," Fisheries Oceanography, vol. 26, no. 3, pp. 251-267, 2017.

[56] E. Willassen, "Haliphron atlanticus steenstrup (Cephalopoda, octopoda) from the coast of Norway," Sarsia, vol. 71, no. 1, pp. 35-40, 1986.

[57] T. Heeger, U. Piatkowski, and H. Moller, "Predation on jellyfish by the cephalopod Argonauta argo," Marine Ecology Progress Series, vol. 88, no. 2-3, pp. 293-296, 1992.

[58] Y. Cherel, V. Ridoux, J. Spitz, and P. Richard, "Stable isotopes document the trophic structure of a deep-sea cephalopod assemblage including giant octopod and giant squid," Biology Letters, vol. 5, no. 3, pp. 364-367, 2009.

[59] M. Guerreiro, R. A. Phillips, Y. Cherel et al., "Habitat and trophic ecology of Southern Ocean cephalopods from stable isotope analyses," Marine Ecology Progress Series, vol. 530, pp. 119-134, 2015.

[60] M. Vecchione, R. E. Young, and U. Piatkowski, "Cephalopods of the northern Mid-Atlantic Ridge," Marine Biology Research, vol. 6, no. 1, pp. 25-52, 2010.

[61] K. Aoki, M. Amano, M. Yoshioka, K. Mori, D. Tokuda, and N. Miyazaki, "Diel diving behavior of sperm whales off Japan," Marine Ecology Progress Series, vol. 349, pp. 277-287, 2007.

[62] K. Aoki, M. Amano, K. Mori, A. Kourogi, T. Kubodera, and N. Miyazaki, "Active hunting by deep-diving sperm whales: 3D dive profiles and maneuvers during bursts of speed," Marine Ecology Progress Series, vol. 444, pp. 289-301, 2012.

[63] T. Kubodera and K. Mori, "First-ever observations of a live giant squid in the wild," Proceedings of the Royal Society B Biological Science, vol. 272, no. 1581, pp. 2583-2586, 2005.

[64] T. Kubodera, Y. Koyama, and K. Mori, "Observations of wild hunting behaviour and bioluminescence of a large deep-sea, eight-armed squid, Taningia danae," Proceedings of the Royal Society B Biological Science, vol. 274, no. 1613, pp. 1029-1034, 2007.

[65] M. Sasaki, "A monograph of the dibranchiata cephalopods of the japanese and adjacent waters," Journal of the Faculty of Agriculture of Hokkaido University, pp. 201-357, 1929.

[66] H. Onda, M. J. Miller, A. Takeshige et al., "Vertical distribution and assemblage structure of leptocephali in the North Equatorial Current region of the western Pacific," Marine Ecology Progress Series, vol. 575, pp. 119-136, 2017.

[67] M. B. Santos, G. J. Pierce, M. García Hartmann et al., "Additional notes on stomach contents of sperm whales Physeter macrocephalus stranded in the north-east Atlantic," Journal of the Marine Biological Association of the United Kingdom, vol. 82, no. 3, pp. 501-507, 2002.

[68] S. L. Watwood, P. J. O. Miller, M. Johnson, P. T. Madsen, and P. L. Tyack, "Deep-diving foraging behaviour of sperm whales (Physeter macrocephalus)," Journal of Animal Ecology, vol. 75, no. 3, pp. 814-825, 2006.
[69] B. Miller, S. Dawson, and R. Vennell, "Underwater behavior of sperm whales off Kaikoura, New Zealand, as revealed by a threedimensional hydrophone array," The Journal of the Acoustical Society of America, vol. 134, no. 4, pp. 2690-2700, 2013.

[70] H. Nakano and M. P. Seki, "Synopsis of biological data on the blue shark, Prionace glauca Linnaeus," Bulletin of the Fisheries Research Agency, vol. 6, pp. 18-55, 2003.

[71] S. E. Campana, A. Dorey, M. Fowler et al., "Migration pathways, behavioural thermoregulation and overwintering grounds of blue sharks in the Northwest Atlantic," PLoS ONE, vol. 6, no. 2, Article ID e16854, 2011.

[72] F. Vandeperre, A. Aires-da-Silva, J. Fontes, M. Santos, R. Serrão Santos, and P. Afonso, "Movements of blue sharks (Prionace glauca) across their life history," PLoS ONE, vol. 9, no. 8, Article ID e103538, 2014.

[73] F. G. Carey, J. V. Scharold, and A. J. Kalmijn, "Movements of blue sharks (Prionace glauca) in depth and course," Marine Biology, vol. 106, no. 3, pp. 329-342, 1990.

[74] N. Queiroz, N. E. Humphries, L. R. Noble, A. M. Santos, and D. W. Sims, "Short-term movements and diving behaviour of satellite-tracked blue sharks Prionace glauca in the northeastern Atlantic Ocean," Marine Ecology Progress Series, vol. 406, pp. 265-279, 2010

[75] N. Queiroz, N. E. Humphries, L. R. Noble, A. M. Santos, and D. W. Sims, "Spatial dynamics and expanded vertical niche of blue sharks in oceanographic fronts reveal habitat targets for conservation," PLoS ONE, vol. 7, no. 2, Article ID e32374, 2012.

[76] M. J. Miller, J. Dubosc, E. Vourey, K. Tsukamoto, and V. Allain, "Low occurrence rates of ubiquitously present leptocephalus larvae in the stomach contents of predatory fish," ICES Journal of Marine Science, vol. 72, no. 5, pp. 1359-1369, 2015.

[77] M. D. Staudinger, F. Juanes, B. Salmon, and A. K. Teffer, "The distribution, diversity, and importance of cephalopods in top predator diets from offshore habitats of the Northwest Atlantic Ocean," Deep-Sea Research Part II: Topical Studies in Oceanography, vol. 95, pp. 182-192, 2013.

[78] H. Watanabe, T. Kubodera, and K. Yokawa, "Feeding ecology of the swordfish Xiphias gladius in the subtropical region and transition zone of the western North Pacific," Marine Ecology Progress Series, vol. 396, pp. 111-122, 2009.

[79] M. Lansdell and J. Young, "Pelagic cephalopods from eastern Australia: Species composition, horizontal and vertical distribution determined from the diets of pelagic fishes," Reviews in Fish Biology and Fisheries, vol. 17, no. 2-3, pp. 125-138, 2007.

[80] T. Romeo, P. Battaglia, C. Pedà et al., "Pelagic cephalopods of the central Mediterranean Sea determined by the analysis of the stomach content of large fish predators," Helgoland Marine Research, vol. 66, no. 3, pp. 295-306, 2012.

[81] G. D. Goodman-Lowe, "Diet of the Hawaiian monk seal (Monachus schauinslandi) from the Northwestern Hawaiian Islands during 1991 to 1994," Marine Biology, vol. 132, no. 3, pp. 535-546, 1998 .

[82] J. Acevedo, E. Carreño, D. Torres, A. Aguayo-Lobo, and S. Letelier, "Cephalopod remains in scats of Weddell seals (Leptonychotes weddellii) at Cape Shirreff, South Shetland Islands, Antarctica," Polar Biology, vol. 38, no. 9, pp. 1559-1564, 2015.

[83] E. L. Donnelly-Greenan, J. T. Harvey, H. M. Nevins, M. M. Hester, and W. A. Walker, "Prey and plastic ingestion of Pacific Northern Fulmars (Fulmarus glacialis rogersii) from Monterey Bay, California," Marine Pollution Bulletin, vol. 85, no. 1, pp. 214224, 2014. 
[84] J. P. Croxall and P. A. Prince, "Dead or alive, night or day: How do albatrosses catch squid?” Antarctic Science, vol. 6, no. 2, pp. 155-162, 1994.

[85] T. Vaske Jr., "Are deep-sea cephalopods really common preys for oceanic seabirds?" Biota Neotropica, vol. 11, no. 1, pp. 177-180, 2011.

[86] M. J. Miller, D. Stepputtis, S. Bonhommeau et al., "Comparisons of catches of large leptocephali using an IKMT and a large pelagic trawl in the Sargasso Sea," Marine Biodiversity, vol. 43, no. 4, pp. 493-501, 2013.

[87] J. C. Xavier, A. L. Allcock, Y. Cherel et al., "Future challenges in cephalopod research," Journal of the Marine Biological Association of the United Kingdom, vol. 95, no. 5, pp. 999-1015, 2015. 


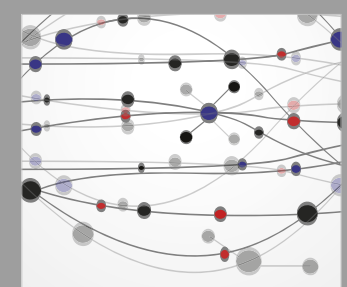

The Scientific World Journal
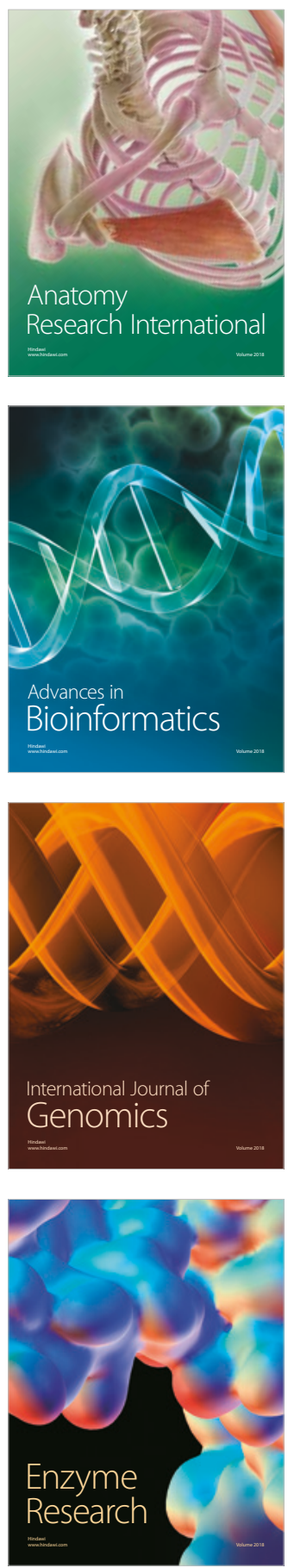
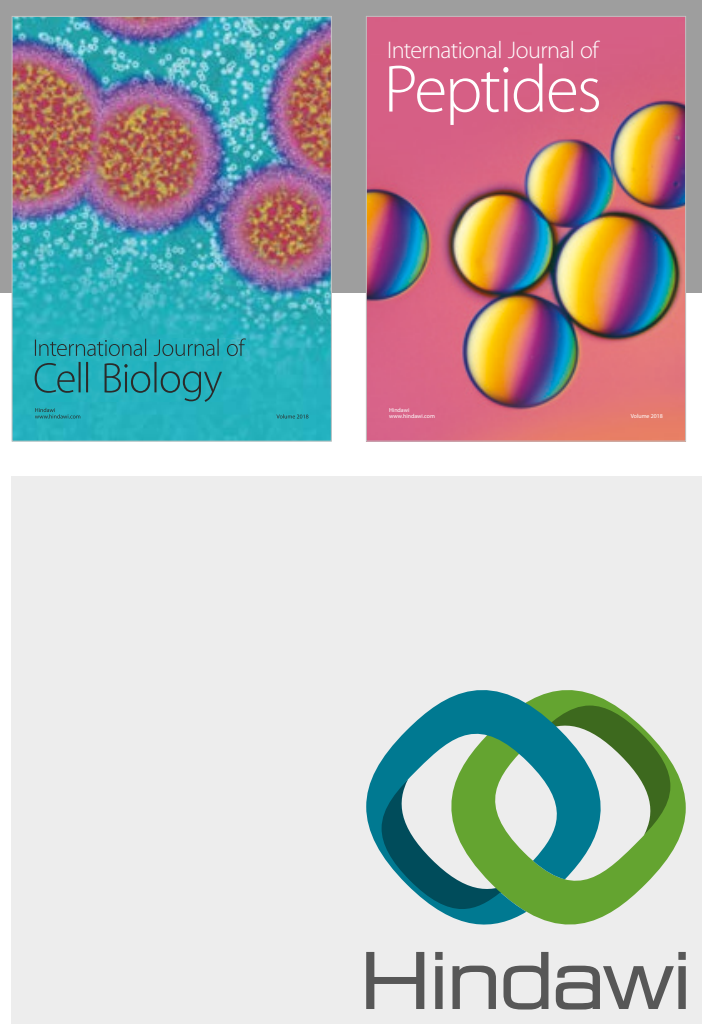

Submit your manuscripts at

www.hindawi.com
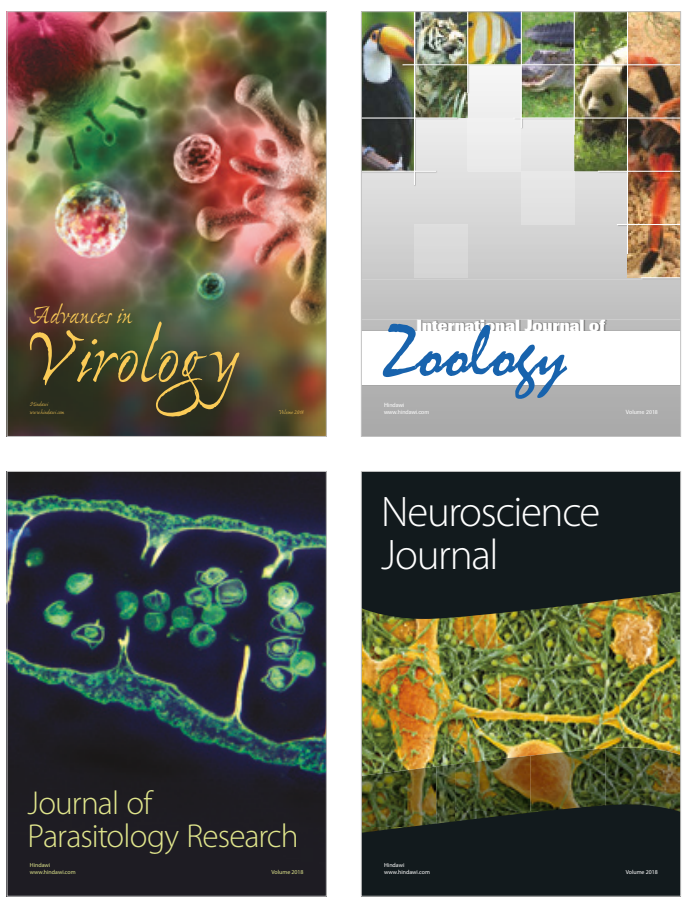
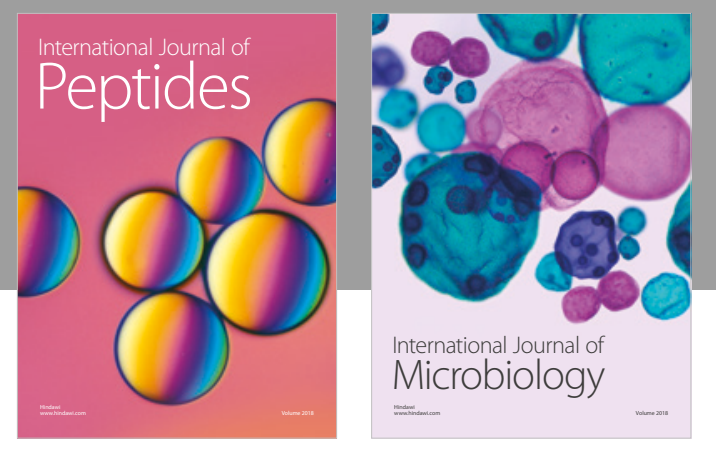

nternational Journal of Microbiology
Journal of
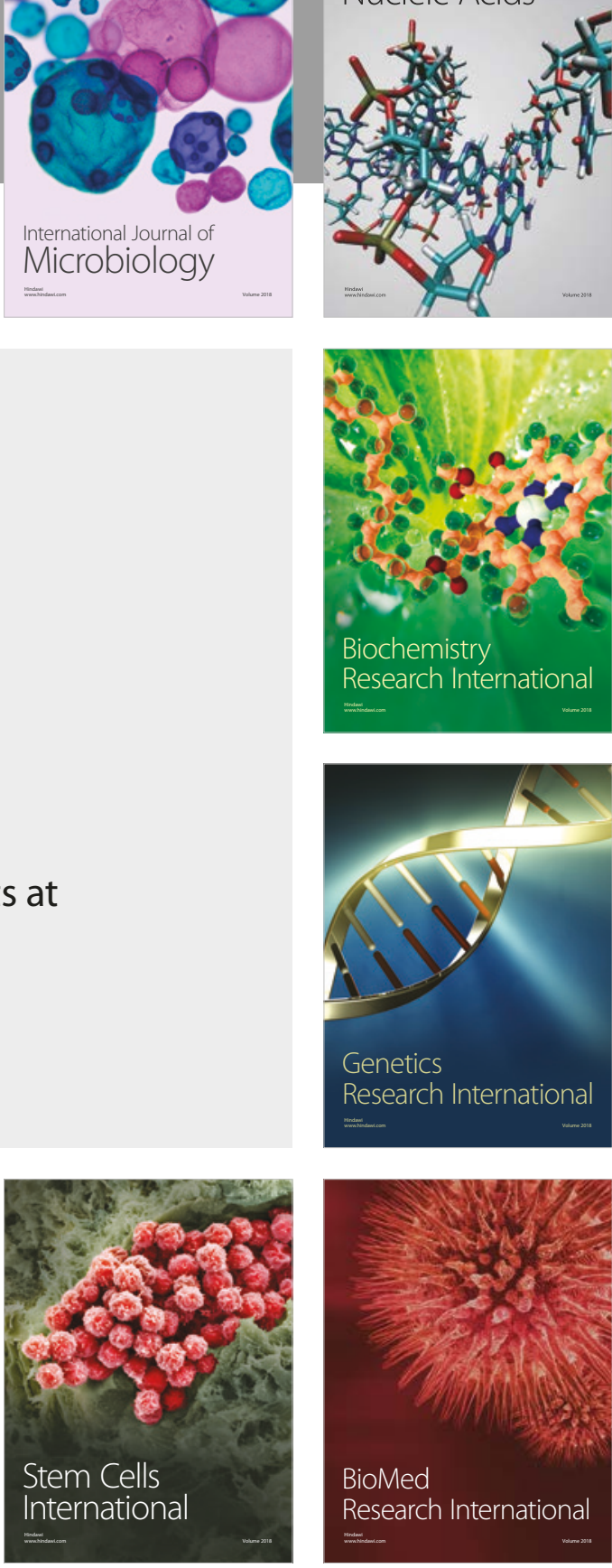
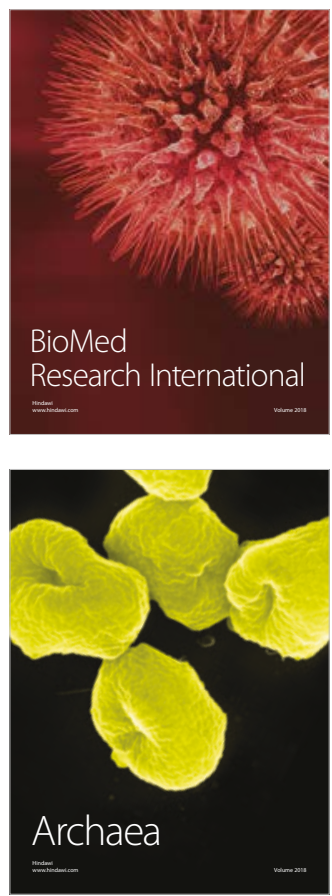